\title{
Agama Sebagai Transpormasi Sosial
}

Eko Nopriyansa
STAI Bumi Silampari Lubuklinggau Indonesia
ekonopriyansyah@gmail.com

\section{Pendahuluan}

Agama memiliki andil yang besar dalam membangun peradaban bangsa, terutama sebagai transpormasi sosial yang akan membantu penguasa atau pemerintah dalam mengatasi masalah-masalah yang sedang dihadapi suatu negara. Dalam sosiologi pengetahuan, kaum Intlektual dimasukkan sebagai kelas sosial baru sebagai kelompok yang menguasai ilmu pengatahuan dan dengan pengetahuannya ini, nampaknya posisi masyarakat intlektual mendapat perhatian sendiri bagi masyarakat luas, karna dengan pengatahuannya diyakini bisa menyampaikan pandangan yang objektif dan netral dalam memberikan pandangan terhadap suatu masalah sosial. Oleh karna itu, Intlektual memiliki ciri khas dengan kemampuannya untuk meng-Edukasi dan menjawab masalah masalah sosial secara kritis, baik melalui pembicaraan ataupun melalui tulisan dalam lingkup public untuk diketahui oleh masyarakat luas, peranan penting sertamemiliki potensi strategis dalam memperbaiki masalah sosial antara lain, tokoh agama, pelopor, dan cendekiawan, dimana mereka memiliki tanggung jawab besar terhadap kondisi dan keadaan masyarakat yang harmonis baik dalam beragama lebih lebih dalam bernegara. (Moeslim Abdurrahman : 23).

Dari berbagai tinjauan aspek yang lebih luas, perubahan sosial kearah yang lebih positif sangat ditentukan oleh peran penting agama, baik dalam bidang pendidikan, ekonomi, kemanusiaan, moral dan lain sebagainya,sebagai praktik sosial yang tidak mungkin semua aspek diserahkan urusannya kepada negara. Dalam sejarah indonesia, sumbangsih pondok pesantren misalnya saja, dalam ikut serta mencerdaskan masyarakat Indonesia tercatat sejak abad ke 15 telah menjadi catatan penting bahwah Agama ikut serta membangun peradaban melalui pendidikan. Namun sangat kita sesali jika fungsi agama yang bisa dijadikan sebagai transpormasi sosial ini, menjadi suatu alat hanya untuk melegimitasi kepentingan kelompok kelempok tertentu saja. 
Tulisan ini, berupaya menjelaskan bagaimana peran penting agama sebagai transpormasi sosial melalui pendidikan secara meluas tentang nilai-nilai agama, karna masalah sosial, merupakan permasalahan yang sangat Urgen bagi keberlangsungan kehidupan beragama,berbangsa dan bernegara.Berbagai masalah sosial yang rawan terjadi, menjadi fokus utama dalam tulisan ini, dengan menampilkan berbagai solusi tentang menjalin hubungan dengan berbagai kelas sosial, baik menyangkut hubungan antar umat beragama, antar kelompok, hingga antar warga negara, diharapkan tulisan ini menjadi nilai tambah dalam memupuk semangat keberagamaan, kebhinekaan, dalam persatuan yang utuh.

\section{Pembahasan}

\section{Konflik Antar Umat Beragama}

Konflik menurut Robert M.Z. Lawang, merupakan perjuangan untuk memperoleh hal-hal yang langkah, seperti nilai, status, kekuasaan dan sebagainya dengan tujuan yang tidak hanya mencari keuntungan, tetapi juga untuk menundukan suatu objek yang dinggap sebagai pesaingnya. Oleh karnanya, bagi Robert terjadinya suatu konflik oleh karena terjadinya benturan kekuatan dan kepentingan untuk merebut sumber kemasyarakatan baik itu ekonomi, politik, sosial dan budaya. Pengertian lain tentang konflik adalah pandangan Kartono, yang memahami konflik sebagai proses sosial yang bersifat Antagonistik dimana suatu keadaan tidak dapat diserasikan dikarenakan kedua kelompok memiliki tujuan, sikap, dan struktural nilai yang berbeda yang tercermin dalam berbagai bentuk perlawanan, baik yang halus, terkontrol, tersembunyi, tidak langsung, terkamuflase maupun yang terbuka dalam bentuk kekerasan. (Kemendikbud RI, 2017 : 120).

Ramainya perbincangan dan kecemasan pemerintah terhadap faham radikalisme belakangan ini, menjadi topik yang selalu diperbincangkan diberbagai media, dalam sejarah kelam Indonesia tahun 1998 yang silam tercatat kasus penganiayaan dan pembunhan Wahidin Nurlete, seorang muslim yang dilakukan oleh mahasiswa Jesuit Marxis yang menggunakan Forkot (Forum Kota) sebagai payung pergerakannya tercatat sebagai sebuah tragedi, lebih lebih pergerakan kelompok ini disokong oleh pihak gareja dengan memberikan bantuan logistikuntuk menggalang pergerakan Jesuit Marxis sehingga mendapat reaksi umat muslim. (Arta Wijaya, 2007 : 2054).

Pendidikan agama hendaknya menjadi prioritas sosial, bukan hanya sekedar di lembaga-lembaga formil yang menyelenggarakan pendidikan, karna setelah pengajaran disekolah, anak-anak masih memerlukan penambahan pengetahuan dan ketrampilan dimasyarakat.Hal ini merupakan Implementasi dari konsep pendidikan seumur hidup yang mengintegerasikan pendidikan keluarga, pendidikan formil, maupun pendidikan diluar sekolah yang diarahkan betul untuk memupuk semangat kebhinekaan ditengah keragaman ras, suku, agama dan budaya ini. Dalam fonomena sosiologis, kurangnya semangat kebhinekaan dan komitmen dalam berbangsa untuk hidup berdampingan akan melahirkan kondisi sosial yang rentan akan perpecahan dan memancing reaksi konflik antar kelompok dalam masyarakat. (Syafarudin, 2005 : 205). 


\section{Agama dan Kegiatan Ekonomi}

Transpormasi Agama dalam bidang ekonomi, adalah spirit yang tidak bisa dipisahkan dari agama, karna esensi agama sejatinya sebagai acuan yang terkadang hukum yang berlaku disuatu negara kewalahan mengatur kegiatan perekonomian ditengah-tengah masyarakat.Didalam karyanya Islam Aplikatif Didin Hafiduddin mengatakan, bahwah secara umum kekhalifahan manusia adalah untuk memakmurkan dan mensejahterakan kehidupan. (Dr. Didin Hafiduddin, 2003 : 26). Secara sistemik Didin menyusun perspektif islam dalam kegiatan ekonomi. Lebih jauh, al-qur'an memerintahkan kita bekerja mencari rezeki yang halal, mendorong umat Islam untuk menguasai dan memanfaatkan sektor dan kegiatan ekonomi dalam skala yang lebih luas dan komprehensif, seperti perdagangan, industry, pertanian, ke-uangan, jasa, dan sebagainya, yang ditujukan untuk kemaslahatan dan kepentingan bersama.

Berangkat dari beberapa perspektif yang dikemukakan, Siklusperekonomianumat Islam tidak boleh menggunakan cara-cara yang batil seperti dengan melakukan kegiatan riba, melakukan penipuan, mempermainkan takaran dan timbangan, berjudi, melakukan praktik suap-menyuap, dan cara bati lainnya.Umat Islam didorong untuk mengoptimalkan pelaksanaan zakat, infak/sedekah, baik pengambilan maupun pendistribusiannya. Optimalisasi zakat, infak/sedekah akan mempunyai pengaruh yang besar terhadap peningkatan kesejahteraan dan kegiatan ekonomi umat.Lebih lanjut, Didin berasumsi bahwah sudah seyogyanya Islam didorong untuk melakukan kegiatan ekonomi dalam kelembagaan yang rapi, teratur, transparan, dan berkordinasi, serta bekerjasama dengan sesama umat Islam.

\section{Agama dalam Pusaran Politik}

Mengutip ungkapan Prof.Dr.Hamkadalam karyanya, keadilan sosial dalam Islam, dengan bersemangat Hamka menceritakan rangkaian sejarah dan gejolak politik Islam yang diakhiri dengan kemunduran Islam dalam memegang tampuk kekuasaan.Oleh karnanya, sebagai bangsa kita bisa mengkaji, bahwah sebetulnya sikap fanatik dan politik identitas dalam kerangka berbangsa dan bernegara adalah tidak ada faedahnya. Lebih gambling, Hamka menuturkan bahwah meletusnya peperangan salib beberapa abad yang lalu dan masuknya turki kekonstantinopel, keluarnya kekuasaan Islam dari spanyol, tidak ada hubungannya dengan keislaman penduduk Indonesia, atau kekristenan penduduk Indonesia. (Prof. Dr. Hamka, 2015 : 182).

Dalam kontesk klasifikasi sosial, politik Indonesia saat ini, persis seperti apa yang digambarkan oleh arta wijaya dalam karyanya dilemma mayoritas bahwah setiap kelompok terdiri dari beberapa komponen, sehingga dalam klasifikasi politik ada yang cenderung terlihat seperti kelompok nasionalis, agamis, danada pula yang terkesan sekuler.Ditengah-tengah kebebasan dan perkembangan teknologi informasi, segala hal terbuka dan dapat diakses oleh siapa saja. Mengutip dari akun media sosial yang mengatasnamakan Sahabat PSI, jauh dari garis besar PSI sebagai partai yang selalu meneriakkan toleransi, dengan keanggotaannya lebih dari 5.000, nampaknya menjadi wadah privasi bagi kelompok ini untuk mempublikasi berbagai pemikirannya, yang kerap terlihat sebagai sebuah wadah yang banyak membidik islam dengan menggiring berbagai Isu, sehingga grup media sosial semacam ini bisa mengancam kesatuan dan 
persatuan tanpa pembinaan dan edukasi.Dari dua sisi fonomena sosial ini, hendaknya setiap umat beragama dan bangsa bisa menyadari bahwah kepentingan sosial lebih penting dari sekedar memperjuangkan hasrat kepentingan kelompok tertentu saja.

\section{Agama dan Kemanusiaan}

Menurut David Litle dalam karyanya kebebasan agama dan hak-hak azazi manusia dengan mengutip pandangan fazlur rahman bahwah tujuan ideologi Islam yang terdapat didalam kitab suci umat islam adalah untuk menciptakan suatu tatanan masyarakat yang adil dan menegakkan konsep amar ma'ruf nahi munkar,maka seyogyanya semua ini akan membuka kesadaran bersama bagi setiap muslim bahwah tugas ini dibebani kepada semua orang. (David Litle,1997: 107). Dalam forum Internasional, Perserikatan Bangsa Bangsa sangat kencang memperjuangkan hak-hak azazi manusia dengan prinsip bahwah martabat dan persamaan melekat pada semua manusia, dan bahwah semua negara anggota telah berjanji pada diri mereka sendiri untuk bersama sama dan menyebarkan aksi kerjasama dengan dengan organisasi itu guna memajukan dan mendorong setiap organisasi negara anggota yang tergabung dengan PBB.

Dalam Islam, kekerasan dan pemberontakan dalam pertarungan politik, bukan merupakan esensi ajaran Islam, dan disinilah peran setiap tokoh komunitas bertanggung jawab untuk memberikan pemahaman yang benar bagi anggota komunitasnya masing-masing. Jhon.L Esposito dalam karyanya Islam Aktual, berupaya menjawab fonomena sejarah politik Islam yang terkesan menggunakan kekerasan ini :

Penguasa dan pemerintahan muslim masa lalu dan saat ini telah menggunakan agama untuk membenarkan dan memobilisasi dukungan untuk perluasan dan penjajahan politik. Ekstrimis agama dari kelompok awal seperti Khawarij dan pergerakan kontemporer seperti jihad Islam Mesir dan al-Qaedah telah menggunakan pandangan Teologis radikal, berdasarkan pada tafsiran kitab suci dan doktrin yang didistorsikan, untuk membenarkan kekerasan dan terorisme melawan masyarakat mereka sendiri dan komunitas internasional. (Jhon. L Esposito, 2005: 139-140).

Dalam catatan sejarah kekristenan, peran agama memiliki andil besar dalam menyulut ketegangan dan kecemasan sosial, mengutip tulisan bustanudin agus bahwah pendekatan keagamaan adalah cara yang paling efektif dalam membentuk kepribadian dan kebudayaan, bustanudin berupaya menyuguhkan contoh beberapa peran agama seperti dominasi gareja katolik roma dizaman pertengahan yang menyebabkan eropa tenggelam dalam The Dark Ages dilawan oleh gerakan Renaissans pada awal abad ke-14. Dan gerakan ini tidak dapat digoyahkan gerakan ilmiah maupun berbagai pemikiran. Sehingga ungkap bustanudin, perlawanan teologis protestan dilanjutkan dengan perlawanan bersenjata dari kalangan kaum protestan diberbagai kerajaan eropa yang memakan waktu selama satu abad dari abad 16 sampai dengan pertengahan abad ke 17 yang pada ummnya diahiri oleh perjanjian toleransi beragama. (Bustanuddin Agus, 2006 : 6). 


\section{Simpulan}

Dalam kehidupan berbangsa dan bernegara, Agama memiliki peran penting dalam mentranspormasi perubahan sosial kearah yang lebih positif. Peran strategis yang bisa di manfaatkan oleh agama tidak hanya terpaku pada pendidikan agama secara formil dilembaga sekolah, namun lebih dari itu pembinaan dan pendidikan nilai-nilai agama bisa memainkan peran pentingnya diberbagai aspek sosial, seperti pendekatan kebudayaan, pembinaan organisasi, mengimplementasi prinsip-prinsip ekonomi islam, membangun paradigma politik Islam sesuai dengan azaz yang diberlakukan.

Dengan demikian, maka agama akan hadir benar-benar sebagai sebuah solusi yang akan membantu jalannya kepentingan negara dan kepentingan umat, jauh dari anggapan bahwah agama adalah sebuah system yang bisa mengancam kedaulatan dan persatuan bangsa. Selain itu bahaya yang menghadang persatuan bangsa, seperti maraknya komunitas radikalisme, intoleran, dapat diatasi dengan melakukan pendidikan dalam pengertian luas diberbagai aspek sejak dini secara kontinyu, sehingga pada ahirnya, nilai-nilai agama bisa diserap dari berbagai aspek dan menjadi sebuah transpormasi sosial yang mengantarkan umat dan bangsa untuk saling bahu membahu membangun negara sesuai fungsinya dengan semangat kebhinekaan. 


\section{DAFTAR PUSTAKA}

Abuddin Nata, 2006. Metodologi Studi Islam, Jakarta: Rajawali Press.

Adian Husaini, 2015. Kerukunan Beragama dan Kontroversi Penggunaan Kata Allah dalam Agama Kristen, Jakarta: Gema Insani.

Bustanuddin Agus, 2005. Agama dalam Kehidupan Manusia, Jakarta: PT. Raja Grafindo Persada.

David Litle dkk. 1997. Kebebasan Agama dan Hak-hak Azazi Manusia, Yogyakarta: Pustaka Pelajar.

Didin Hafiduddin. 2003. Islam Aplikatif, Jakarta: Gema Insani.

Hamka. 2015. Keadilan Sosial dalam Islam, Jakarta: Gema Insani.

Jhon.L Esposito, 2005. Jawaban atas Gejolak Masyarakat Post-Modern, Islam Aktual, Depok: Inisiasi Press.

Kemendikbud. 2017. Ilmu Pengatahuan Sosial, Jakarta: Balitbang.

Moeslim Abdurrahman. 2003. Islam Sebagai Kritik Sosial, Jakarta: Penerbit Erlangga.

Muhammad Imarah, 1999. Islam dan Pluralitas Perbedaan dan Kemajemukan dalam Bingkai Persatuan, Jakarta: Gema Insani.

Robert D. Lee, 2000. Mencari Islam Autentik, Bandung: Penerbit Mizan.

Rohimin dkk.2009. Harmonisasi Agama dan Budaya di Indonesia, Jakarta: Balitbang.

Syarifuddin, 2005. Manajemen Lembaga Pendidikan Islam, Jakarta: PT. Ciputat Press. 